\title{
Lack of effect of cell-wall targeted antibacterials on biofilm formation and antifungal susceptibility of Candida species
}

\author{
Gisela Myrian de Lima Leite ${ }^{1, *}$, Lílian Cristiane Baeza², Rosana Teixeira Ramos ${ }^{3}$, Sérgio Seiji \\ Yamada $^{3}$, Thiago Ferreira dos Santos Magon ${ }^{4}$, Elza Kimura ${ }^{4}$, Terezinha Inez Estivalet Svidzinski ${ }^{2}$ \\ ${ }^{1}$ Pharmacy Service, University Hospital of Maringá, State University of Maringá, Maringá, PR, Brazil, ${ }^{2}$ Clinical Mycology \\ Laboratory, State University of Maringá, Maringá, PR, Brazil, ${ }^{3}$ Department of Medicine, University Hospital of Maringá, State \\ University of Maringá, Maringá, PR, Brazil, ${ }^{4}$ Department of Pharmacy, State University of Maringá, Maringá, PR, Brazil
}

\begin{abstract}
The use of central venous catheters $(\mathrm{CVC})$ and broad-spectrum antibacterials are among the main risk factors for the development of candidemia in patients admitted to intensive care units (ICU). It is known that some antibacterials increase the resistance of these yeasts to azole antifungals. Thus, the aim of this research was to determine whether yeast present in CVC colonizations previously exposed to cellwall targeted antibacterials benefit from a reduction in susceptibility to fluconazole and voriconazole, facilitating their ability to form biofilms. Candida albicans, C. tropicalis, C. glabrata, C. parapsilosis and C. guilhermondii were seeded into antibacterial (cefepime, meropenem, vancomycin, and piperacillintazobactam) gradient plates produced in Mueller-Hinton Agar. The susceptibility to fluconazole and voriconazole and the biofilm formation of the yeasts were tested before and after exposure to the antibacterials. None of the antibacterials exerted a significant effect on the in vitro susceptibility of the yeasts to the antifungal agents or on their ability to form biofilms. These results suggest that increased candidemia in ICU patients is not attributable to possible alterations in the yeasts, but is more likely caused by a weakening of the patient's general condition after long exposure to infection.
\end{abstract}

Uniterms: Central venous cateter/use. Candidemia/control. Biofilm/formation. Antibacterials. Antifungals. Candida/species/control..

O uso de cateter venoso central (CVC) e antibióticos de amplo espectro estão entre os principais fatores de risco para o desenvolvimento da candidemia em pacientes internados em unidades de terapia intensiva (UTI). É conhecido que alguns antibióticos aumentam a resistência das leveduras aos antifúngicos azólicos. Assim, o objetivo deste estudo foi avaliar se leveduras presentes em colonização de CVC expostas a antibióticos que atuam em parede celular se beneficiam de uma redução na suscetibilidade ao fluconazol e voriconazol e se obtêm maior capacidade de formar biofilme. Candida albicans, $C$. tropicalis, C. glabrata,C. parapsilosis e C. guilhermondii foram semeadas em placas de Mueller-Hinton Agar, com gradientes de antibióticos (cefepima, meropenem, vancomicina e piperacilina-tazobactam). A suscetibilidade e a formação de biofilme das leveduras foram testadas antes e após a exposição aos antibióticos. Nenhum dos antibióticos provocou alterações detectáveis in vitro sobre a suscetibilidade das leveduras aos antifúngicos ou à capacidade de formar biofilme. Estes resultados sugerem que o aumento da candidemia na UTI não seria atribuído a possíveis alterações provocadas nas leveduras e sim pelo enfraquecimento da condição geral do paciente após longa exposição à infecção.

Unitermos: Cateter venoso central/uso. Candidemia/controle. Biofilme/formação. Antibióticos. Antifúngicos. Candida/espécies/controle.

*Correspondence: G. M. L. Leite. Divisão de Farmácia Hospitalar, Hospital Universitário Regional de Maringá. Avenida Mandacaru, 1590, Zona 7, 87083 240 - Maringá - PR, Brasil. E-mail: gmlleite@gmail.com 


\section{INTRODUCTION}

The incidence of candidemia in tertiary public hospitals in Brazil is approximately 2.5 cases per 1000 hospital admissions (Colombo et al., 2013). Candida species are the fourth-most-common etiological agent of nosocomial bloodstream infections (BSIs), and have a mortality rate of over $40 \%$. Risk-factors for invasive candidiasis include the use of central venous catheters (CVC) and broad-spectrum antibacterials. In one study, CVCs were considered the main source of fungemia in more than $80 \%$ of cases (Lin et al., 2005). A previous study conducted at the University Hospital of Maringá found a rate of yeast colonization of CVCs of 10.89\% (Ramos et al., 2011).

Treatment with two or more broad-spectrum antibacterials is associated to an imbalance in the endogenous flora which enables yeasts to overgrow (Lin et al., 2005). Furthermore, some antibacterials are able to change the susceptibility profile of yeasts to antifungals by over expressing resistant genes (Vogel et al., 2008; Oliver et al., 2008) or by increasing their ability to form biofilms (McCool et al., 2008).

Protein-synthesis targeted antibacterials, such as rifampicin and tetracycline, act on the antifungal activities of fluconazole. Rifampicin induces the activation of Candida albicans multi drug resistant-1 (MDR1) genes to fluconazole (Vogel et al., 2008), while tetracycline alters the gene expression of ergosterol biosynthesis increasing resistance to fluconazole and terbinafine (Oliver et al., 2008), while also increases $C$. albicans virulence, hyphae formation and, to a lesser extent, drug efflux and the formation of biofilms (McCool et al., 2008).

Since the vast majority of ICU patients have CVCs inserted and receive at least one antibacterial for prophylaxis or treatment, the overgrowth of yeasts is a serious concern which may lead to a worsening of their diseases, prolonged hospitalization and increased mortality rates (Lin et al., 2005).

The investigations of interactions of the antibacterials with the antifungals reported above only cite drugs that affect RNA and protein synthesis, rifampicin and tetracycline, respectively. However, no studies have been carried out with antibacterials that act on cell-wall synthesis.

Therefore, the objective of the present study was to evaluate, in vitro, whether yeast present in CVC colonizations, which have been exposed to antibacterials that act on bacterial cell-wall synthesis, undergo alterations in their susceptibility to fluconazole and voriconazole and in their ability to form biofilms.

\section{MATERIAL AND METHODS}

\section{Material}

The antibacterials cefepime (Aurobindo Pharma Limited), meropenem (Instituto BioChimico Indústria Farmacêutica Ltda), piperacillin-tazobactam and vancomycin (Novafarma Indústria Farmacêutica Ltda) were purchased by the University Hospital of Maringá, Brazil, and used in this research with permission. The antifungals fluconazole and voriconazole were purchased from Sigma Chemical Co.

The working concentrations of the antibacterials cefepime (24 mg/L), meropenem (12 mg/L), piperacillintazobactam $(192 \mathrm{mg} / \mathrm{L})$ and vancomycin $(20 \mathrm{mg} / \mathrm{L})$ were established according to their pharmacodynamic targets against: Enterobacteria $(3 \times$ MIC $\leq 8 \mu \mathrm{g} / \mathrm{mL}$ for cefepime and $3 \times \mathrm{MIC} \leq 4 \mu \mathrm{g} / \mathrm{mL}$ for meropenem), Pseudomonas aeruginosa (4 x MIC $\leq 64 / 4 \mu \mathrm{g} / \mathrm{mL}$ for piperacillin-tazobactam) and Staphylococcus aureus ( $5 \times$ MIC $\leq 4 \mu \mathrm{g} / \mathrm{mL}$ for vancomycin), as established by the Clinical and Laboratory Standard Institute (CLSI, 2005), Mattoes et al. (2004) and Rybak (2006).

\section{Sampling collection}

The study protocol was approved by the Local Research Ethics Committee prior to sample collection (authorization number 251/07). Five yeasts isolated in a previous study (Ramos et al., 2011) were included in this evaluation.

\section{Antifungal susceptibility test}

The minimal inhibitory concentrations (MIC) of fluconazole and voriconazole against the yeasts were obtained by broth microdilution according to the Clinical and Laboratory Standards Institute (CLSI, 2008). C. parapsilosis ATCC 22019 was used as a reference.

\section{Antifungal susceptibility test of yeasts pre-treated with antibacterials}

The yeasts were pre-treated with antibacterials by using a gradient of concentration system on slanted plates as described by Szybalski, Bryson (1952). Briefly, bases $(10 \mathrm{~mL})$ of Mueller-Hinton Agar (MHA) were solidified in the plates over slanted supports to provide inclined layers $\left(30^{\circ}\right)$ of culture medium, thus obtaining different thicknesses of medium. Second layers of MHA $(10 \mathrm{~mL})$ containing $10^{6}$ colony-forming units per milliliter 
$(\mathrm{CFU} / \mathrm{mL})$ of one of the yeast suspensions mixed with one of the antibacterials were added over the inclined layers and allowed to solidify to form flat surfaces. The plates were incubated at $35^{\circ} \mathrm{C}$ for two days. The concentration of each antibacterial was therefore dependent on the thickness of the medium and the diffusion rate of the antibacterial.

The colonies which grew in the three regions of the antibacterial plates (high, intermediate and low concentration) were collected and tested for susceptibility to fluconazole and voriconazole, as described by CLSI, and for biofilm formation as described by Shin et al., (2002).

A confirmatory test was carried out by mixing all the antibacterials at a fixed concentration and performing susceptibility tests against fluconazole and voriconazole for all of the yeasts.

\section{Biofilm formation}

To test for the formation of biofilms, suspensions of the yeast isolates, both treated and non-treated with antibacterials, were adjusted to a concentration of $3.7 \times 10^{7} \mathrm{CFU} / \mathrm{mL}$ and $20 \mu \mathrm{L}$ of each suspension was added to 96 -well polystyrene microplates containing $180 \mu \mathrm{L}$ of Sabouraud Dextrose Broth (SDB) with glucose at a final concentration of $8 \%$. The microplates were incubated at $35^{\circ} \mathrm{C}$ for $24 \mathrm{~h}$ and the transmittance $(\% \mathrm{~T})$ of each well was measured on an ASYS Expert Plus microplate reader at a wavelength of $405 \mathrm{~nm}$. Wells containing only SDB without yeast suspensions were used as a negative control.
The degree of biofilm production was measured according to Shin et al., 2002.

\section{RESULTS AND DISCUSSION}

C. tropicalis, C. glabrata, C. albicans, $C$. parapsilosis and C. guilhermound, previously isolated from CVC colonizations, were used to determine the influence of antibacterials on antifungal activity. All of the yeasts were susceptible to fluconazole and voriconazole, $\mathrm{MIC} \leq 8 \mu \mathrm{g} / \mathrm{mL}$ and $\mathrm{MIC} \leq 1 \mu \mathrm{g} / \mathrm{mL}$, respectively, while the highest MIC value $(8 \mu \mathrm{g} / \mathrm{mL})$ was for fluconazole against $C$. glabrata. For all of the yeasts tested, in vitro susceptibility to fluconazole and voriconazole after prior exposure to antibacterials did not differ significantly to that of the non-treated control groups (Table I). The additional susceptibility test, in which the antibacterials and antifungals were mixed together at the same time, produced the same results as those found in the antibacterial pre-treatment tests.

Many studies have emphasized that antibacterials induce a high risk of candidemia (Lin et al., 2005). However, no studies have confirmed the lack of effect of antibacterials on antifungal drugs against Candida spp. The present research is the first study to have investigated possible interactions between cell-wall targeted antibacterials and fluconazole or voriconazole used against $C$ andida spp.

Several studies have reported that prior treatment with antibacterials and fluconazole is a high-risk factor for candidemia and can induce resistant non-albicans

TABLE I - In vitro susceptibility test with voriconazole and fluconazole for Candida species pre-treated with cell-wall targeted antibacterials

\begin{tabular}{|c|c|c|c|c|c|c|c|c|}
\hline \multirow{3}{*}{ Antifungals } & \multirow{3}{*}{ Antibacterials } & \multicolumn{7}{|c|}{ MIC $(\mu \mathrm{g} / \mathrm{mL})$ values for Candida } \\
\hline & & \multirow[t]{2}{*}{ tropicalis } & \multirow[t]{2}{*}{ glabrata } & \multirow[t]{2}{*}{ guilliermondii } & \multicolumn{2}{|c|}{ albicans } & \multicolumn{2}{|c|}{ parapsilosis } \\
\hline & & & & & 1 & 2 & 1 & ATCC \\
\hline \multirow{5}{*}{ Fluconazole } & Non-treated Control & 0.5 & 8 & 0.5 & 0.25 & 0.125 & 0.5 & 2 \\
\hline & $\mathrm{V}$ & 0.25 & 8 & 1 & 0.25 & 0.125 & 0.5 & 2 \\
\hline & PT & 0.5 & 8 & 0.5 & 0.25 & 0.125 & 0.5 & 2 \\
\hline & M & 0.5 & 8 & 0.5 & 0.25 & 0.125 & 0.5 & 1 \\
\hline & $\mathrm{C}$ & 0.25 & 8 & 0.5 & 0.25 & 0.125 & 0.5 & 1 \\
\hline \multirow{5}{*}{ Voriconazole } & Non-treated Control & 0.03 & 0.5 & 0.03 & 0.03 & 0.03 & 0.03 & 0.06 \\
\hline & $\mathrm{V}$ & 0.03 & 0.5 & 0.03 & 0.03 & 0.03 & 0.03 & 0.03 \\
\hline & PT & 0.03 & 0.25 & 0.03 & 0.03 & 0.03 & 0.03 & 0.03 \\
\hline & M & 0.03 & 0.5 & 0.03 & 0.03 & 0.03 & 0.03 & 0.06 \\
\hline & $\mathrm{C}$ & 0.03 & 0.5 & 0.03 & 0.03 & 0.03 & 0.03 & 0.03 \\
\hline
\end{tabular}

Minimal Inhibitory Concentration (MIC); Vancomycin(V); Piperacillin-tazobactam (PT); Meropenem (M); Cefepime (C). 
Candida (Lin et al., 2005; Playford et al., 2008). This increased resistance has been observed with candidemia caused by $C$. glabrata and $C$. kruzei after prolonged treatment with vancomycin and piperacillin-tazobactam (Lin et al., 2005). The data from these studies suggests that antibacterials may, to some degree, affect antifungal activity and induce resistant genes in yeasts, as has been observed with rifampicin, doxycycline and tigecycline (Vogel et al., 2008).

Rifampicin and tigecycline inhibit the synthesis of RNA and proteins, and induce the over expression of genes that are resistant to fluconazole (Vogel et al., 2008; Oliver et al., 2008). In the vast majority of studies, cellwall targeted antibacterials are also included among those thought to produce a higher risk of candidemia as they are used extensively against nosocomial infections in clinical practice.

In fact, based on the mechanism of action of cell-wall targeted antibacterials, they are not expected to act on the cell walls of yeast since the compositions of the cell walls of bacteria and yeast are completely different. The critical target of cell-wall antibacterials is the peptidoglycan layer of bacteria, whereas the target of antifungals is the ergosterol layer of yeast.
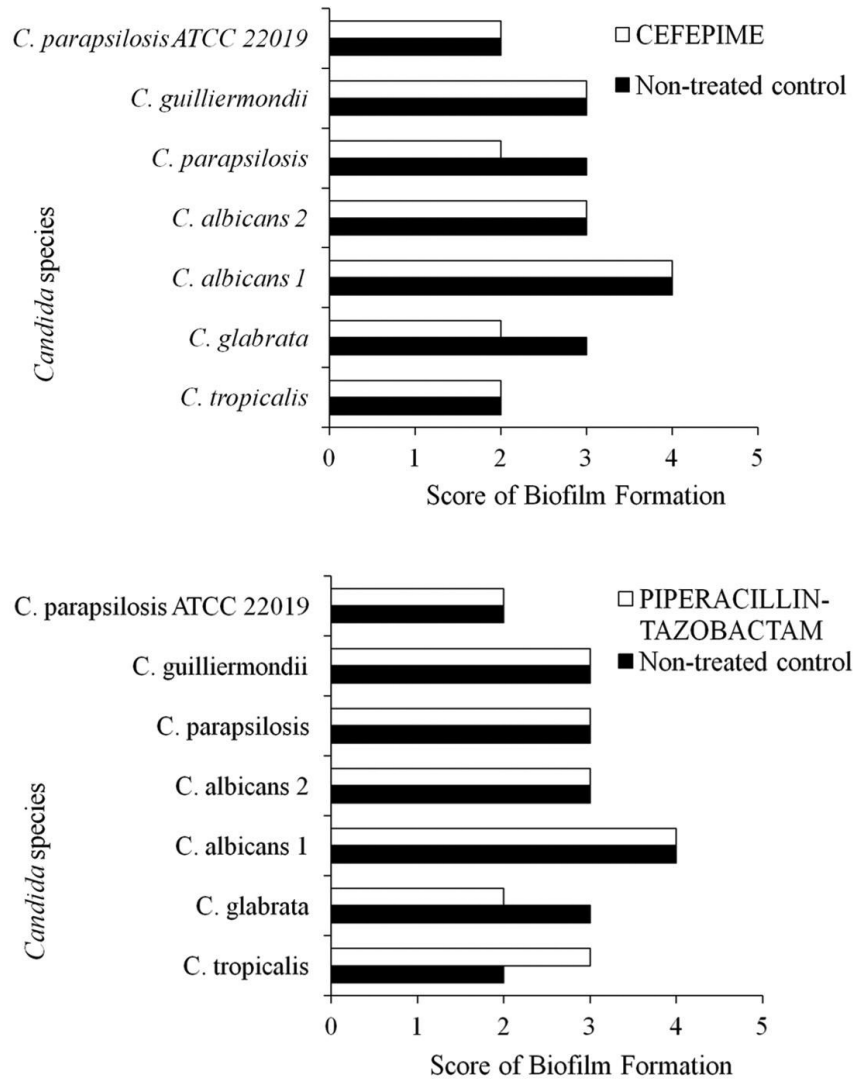

The candidemia observed after prolonged antibacterial therapy seems to be more attributable to the patient's general condition after long exposure to infection and a selection of resistant microbiota, or secondary to chronic renal disease and solid organ transplantation (Playford et al., 2008).

Biofilm formation is an important virulence factor in fungal infections among ICU patients. Therefore, the influence of antibacterials on the ability of the yeast to form biofilms was also tested. As can be seen in Figure 1, C. albicans showed the greatest capacity to form biofilms whereas $C$. tropicalis showed the lowest, both for treated and non-treated samples. In this study, the ability to form biofilms was not influenced by the presence of the antibacterials, even at high concentrations. This finding is important, since biofilms are complex polymicrobial associations anchored to abiotic or biotic surfaces, embedded in extracellular matrix produced by the biofilms themselves, where they interact with each other and the environment. One of the main properties of biofilms is their capacity to be more resistant to antimicrobial agents than planktonic cells (Shin et al., 2002).

These results demonstrate that cell-wall targeted antibacterials do not affect the biofilm-forming capacity
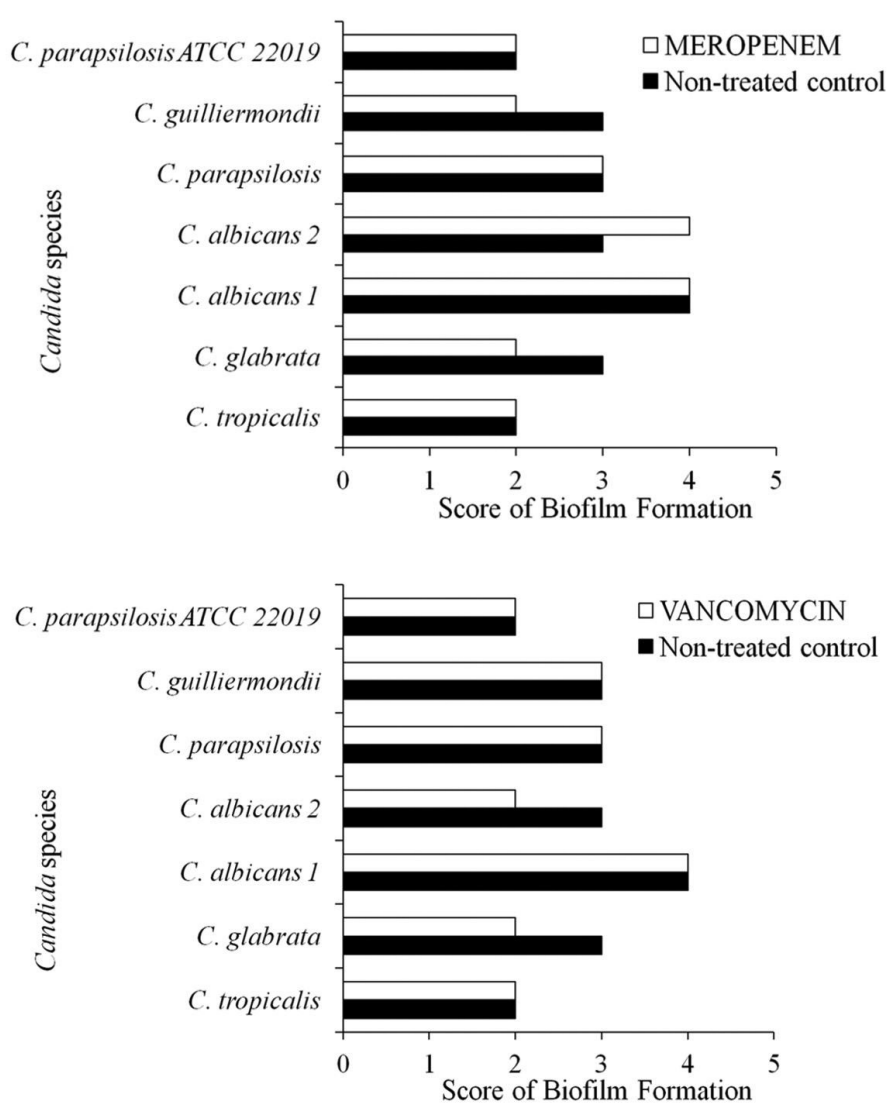

FIGURE 1 - Capacity of Candida species to form biofilm after treatment with antibacterials. 
of Candida spp. Based on these results, it can be concluded that fungemia caused by Candida spp. is not directly influenced by the presence of cell-wall targeted antibacterials.

One limitation of this study is that the gene expression of Candida species treated with antibacterials was not explored. Nevertheless, this study reports a negative result which, from a clinical point of view, is important because it removes speculation about the possibility that cell-wall targeted antibacterials can induce candidemia by interfering with the antifungal activity of fluconazole and voriconazole.

Another speculative argument for antibacterials causing candidemia is that cell-wall targeted antibacterials may indirectly induce candidemia by potentiating host-directed inflammatory responses against invasive bacterial pathogens by releasing pro-inflammatory cell-wall components and intracellular toxins following bacteriolysis. This effect may exacerbate the inflammatory reactions damaging the host cell and tissues, worsening the patient's condition. However this same effect has not been observed with antibacterials such as macrolides, fluoroquinolones and tetracyclines, as these prevent the release of pro-inflammatory toxins of Gram positive and Gram-negative bacteria and also inhibit other virulence factors working against the excessive production of several potent inflammatory mediators (Anderson et al., 2010). This difference in the mechanism of action of these classes of antibacterials may explain, in part, why all epidemiological risk factors point to the cell-wall targeted antibacterials and not to the protein-synthesis targeted antibacterials.

This study corroborates the results found by Playford et al.,(2008), who claimed that there was no correlation between antibacterial drugs exposure and infection by Candida spp. Using data from a large surveillance program, prior systemic antifungal exposure, prior gastrointestinal surgery, increasing age, and intravenous drug use were independently significant risk factors associated with non-candida and fluconazole-resistant Candida spp among ICU patients with candidemia, while pre-treatment with antibacterials were not significant.

\section{CONCLUSIONS}

In conclusion, this study proved that cell-wall targeted antibacterials do not affect Candida spp. growth and biofilm formation, and rejects the hypothesis that these antibacterials interact with antifungals to decrease their antifungal activity akin to protein-biosynthesis targeted antibacterials.

\section{ACKNOWLEDGMENTS}

The authors would like to thank the University Hospital of Maringá and the Clinical Mycology Laboratory of the State University of Maringá for providing the clinical isolates.

\section{REFERENCES}

ANDERSON, R.; TINTINGER, G.; COCKERAN, R.; POTJO, M.; FELDMAN, C. Beneficial and harmful interactions of antibiotics with microbial pathogens and the host innate immune system. Pharmaceuticals, v.3, p.1694-1710, 2010.

CLINICALAND LABORATORY STANDARDS INSTITUTE. CLSI. Performance standards for antimicrobial susceptibility testing. Wayne, 2005. (M100-S-15 Fifteenth Informational Supplement).

CLINICALAND LABORATORY STANDARDS INSTITUTE. CLSI. Reference method for broth dilution antifungal susceptibility testing of yeasts. Wayne, 2008. (M27-A-3. Approved Standard-Third Edition).

COLOMBO, A.L.; GUIMARÃES, T.; CAMARGO, L.F.; RICHTMANN, R.; DE QUEIROZ-TELLES, F.; SALLES, M.J.; DA CUNHA, C.A.; YASUDA, M. A.; MORETTI, M.L.; NUCCI, M. Brazilian guideline for the management of candidiasis - a joint meeting report of three medical societies: Sociedade Brasileira de Infectologia, Sociedade Paulista de Infectologia and Sociedade Brasileira de Medicina Tropical. Braz. J. Infect. Dis., v.17, p.283-312, 2013.

LIN, M.Y.; CARMELI, Y.; ZUMSTEG, J.; FLORES, E.L.; TOLENTINO, J.; SREERAMOJU, P.; WEBER, S.G. Prior antimicrobial therapy and risk for hospital-acquired Candida glabrata and Candida krusei fungemia: a casecase-control study. Antimicrob. Agents Chemother., v.49, p.4555-4560, 2005.

MATTOES, H.M.; KUTI, J.L.; DRUSANO, G.L.; NICOLAU, D.P. Optimizing antimicrobial pharmacodynamics: dosage strategies for meropenem. Clin. Ther., v.26, p.1187-1198, 2004.

MCCOOL, L.; MAI, H.; ESSMANN, M.; LARSEN, B. Tetracycline effects on Candida albicans virulence factors. Infect. Dis. Obstet. Gynecol., v.2008, p.1-7, 2008. 
OLIVER, B.G.; SILVER, P.M.; MARIE, C.; HOOT, S.J.; LEYDE, S.E.; WHITE, T.C. Tetracycline alters drug susceptibility in Candida albicans and other pathogenic fungi. Microbiology, v.154, p.960-970, 2008.

PLAYFORD, E.G.; MARRIOTT, D.; NGUYEN, Q.; CHEN, S.; ELLIS, D.; SLAVIN, M.; SORRELL, T.C. Candidemia in nonneutropenic critically ill patients: risk factors for non-albicans Candida spp. Crit. Care Med., v.36, p.20342039, 2008.

RAMOS, R.T.; LEITE, G.M.; MARTINEZ, H.V.; SIBIN, K.C.; GERMANO, A.; SVIDZINSKI, T. Clinical and epidemiological characteristics of patients with central venous catheter colonized by yeasts. Acta Med. Port., v.24, suppl.2, p.257-262, 2011.

RYBAK, M.J. The pharmacokinetic and pharmacodynamic properties of vancomycin. Clin. Infect. Dis., v.42, suppl.1, p.35-39, 2006.
SHIN, J.H.; KEE, S.J.; SHIN, M.G.; KIM, S.H.; SHIN, D.H.; LEE, S.K.; SUH, S.P.; RYANG, D.W. Biofilm production by isolates of Candida species recovered from nonneutropenic patients: comparison of bloodstream isolates with isolates from other sources. J. Clin. Microbiol., v.40, p.1244-1248, 2002.

SZYBALSKI, W.; BRYSON, V. Genetic studies on microbial cross resistance to toxic agents. I. Cross resistance of Escherichia coli to fifteen antibiotics. J. Bacteriol., v.64, p.489-499, 1952.

VOGEL, M.; HARTMANN, T.; KÖBERLE, M.; TREIBER, M.; AUTENRIETH, I.B.; SCHUMACHER, U.K. Rifampicin induces MDR 1 expression in Candida albicans. J. Antimicrob. Chemother., v.61, p.541-547, 2008.

Received for publication on $04^{\text {th }}$ February 2013 Accepted for publication on $12^{\text {th }}$ November 2013 